\title{
ФІЛОСОФІЯ ФОРМУВАННЯ І РОЗВИТКУ ПОЧУТТІВ
}

\author{
Т. Б. Кадобний, Л. В. Кравчук, І. З. Боцюк \\ ДВНЗ “Тернопільський державний медичний університет \\ імені I. Я. Горбачевського МОЗ Украӥни”
}

\section{PHILOSOPHY OF FEELINGS' FORMING AND DEVELOPMENT}

\author{
T. B. Kadobnyi, L. V. Kravchuk, I. Z. Botsyuk \\ SHEI "Ternopil State Medical University by I. Ya. Horbachevsky of MPH Ukraine"
}

\begin{abstract}
У статті розкрито природу виникнення почуттів, їх розвиток та методи управління ними. Крім того, вказано на необхідність формування позитивних почуттів у студентів як на практичних, так і теоретичних заняттях.

The article deals with the nature of the emergence of feelings, their development and management techniques that form the content of mental processes. In addition, it insists on the necessity of forming positive feelings among the students during the practical as well as the theoretical classes.
\end{abstract}

Вступ. Кожен акт нашої діяльності супроводжується тими чи іншими почуттями, і ми переживаємо їх не тільки залежно від певного фізичного стану, змісту духовних явищ, але й від внутрішніх душевних процесів, які ще й мають велику кількість відтінків.

Проблема взаємозв'язку навчання і розвитку [1] не втратила актуальності і сьогодні.

Для викладацької діяльності немає особливої необхідності розглядати всі види почуттів. Особливу увагу слід звернути на ставлення викладача та його налаштування до аудиторії, а потім варто зупинитися на тих почуттях, з якими йому доволі часто доводиться зустрічатися та долати їх або протистояти їм (байдужість, бездіяльність, страх, гнів), і на тих, які йому необхідно розвивати і зміцнювати, тому що вони вивищують, облагороджують людину (естетичні, моральні, духовні почуття), розширюють соціальне оточення, сферу контактів [2].

Почуття виникають на грунті інстинктивних потреб і отримують вищий ступінь сили залежно від фізичних та психологічних особливостей натури. За однакових умов одні натури більше піддаються страхові або радості, ніж інші.

Вроджена здатність до почуттів не знижує можливості їх розвитку та пригнічення. Вони розвиваються, глибоко проникають у душу. Кожне нове почуття пробуджує минулі споріднені почуття і з їх допомогою діє ще сильніше.

Основна частина. Отже, щодо природи почуттів i їх розвитку легко вивести загальні правила для роз-

(c) Т. Б. Кадобний, Л. В. Кравчук, І. 3. Боцюк витку добрих почуттів та пригнічення негативних у процесі практичної діяльності. Для цього необхідно, по-перше, відмежувати студентів від усіх чинників, що збуджують негативні почуття, i оточити їх сприятливою науково-дослідною, пошуковою, естетичною атмосферою, яка здатна викликати позитивні та хороші почуття, стимулюючи інтерес до виважених дій. Постійно спрямовуючи студентів в таке русло, ми не даємо можливості розвиватися і зміцнюватися в них негативним почуттям і таким чином створюємо грунтовну мотивацію для необхідних напрямів діяльності молоді.

По-друге, почуття завжди знаходять вираження в рисах обличчя, жестах, у звуковій інтонації тощо. Кожне почуття має свої чіткі й всім зрозумілі вияви зовні. Зв'язок між почуттями і тілесними проявами такий тісний, що засвоюючи зовнішні прояви якогонебудь почуття, ми можемо викликати його в душі. Тому доцільно контролювати будь-які почуття.

По-третє, під час розвитку почуттів у студентів необхідно розвивати і роздуми про ті чи інші почуття. Якщо молоді люди шляхом розмірковування і аналізу позитивних і негативних почуттів усвідомлять перевагу одних над іншими, тоді вони самі будуть намагатись прагнути до позитивних та уникати негативних. В основному, виділяють два напрямки позитивних і негативних почуттів, які тісно переплітаються зі студенським Я та, в перспективі із дорослим Я. Від того, які будуть домінувати почуття у формувані молодої людини, залежать якості майбутньої особистості. Через тісну взаємодію почуттів із 
нашим Я життя почуттів стає найбільш утаємниченою стороною духовного життя.

Позитивні і приємні почуття необхідно підтримувати і зберігати - це основний напрям контролю над ними. А основний принцип - це дотримання міри, бо тривале почуття, навіть позитивне, може перерости у свою протилежність через надмірність. Тому контроль над почуттями є важливим елементом роботи викладача.

Людина наділена інтелектуальними та емоційними якостями, кожен акт своєї життєдіяльності супроводжує не лише осмислення, а й реакцію своїх почуттів, які формуються змістом душевних процесів, впливом оточення, власне психодуховним станом, здоров’я i, водночас, здійснюється здоровий вплив на загальні чинники.

Основним правилом розвитку почуттів у студентів $\epsilon$ необхідність відокремлення позитивних почуттів від негативних з одночасною стимуляцією перших і гальмуванням других, в чому надзвичайно важливу роль відіграє осмислене ставлення молодих людей до власних почуттів, їх аналіз, висновки щодо наслідків їх прояву. Останне тисячоліття характеризується зміною домінування в різні періоди життя людей трьох основних складових цілісної людини: духу, розуму і тіла. Період домінування духу і релігійності змінився періодом домінування розуму і науки, а той, у свою чергу, періодом домінування комфорту і тілесних бажань. Сьогодні керує тіло, а його пристрастям служить покалічений розум з комп'ютером в кишені [1]. А тому молодій людині у всьому цьому розібратись самотужки складно.

Якщо молоді люди шляхом розмірковування аналізу позитивних та негативних почуттів усвідомлюють перевагу одних над іншими, тоді вони самі будуть намагатись прагнути до позитивних та уникати негативних. Цінні самі по собі, почуття є важливіші ще й тому, що, здійснюючи вплив на наше тілесне і духовне життя, формують нові установки і цінності, мотиви й інтереси, загальні якості особистості [3]. Думки і вчинки залежать значною мірою від певних почуттів, які приносять нам радість та задоволення або смуток та проблеми.

Складні почуття складаються з простих, а тому виховання почуттів повинно розпочинатися із впливу на прості почуття. Власне відчуття, а також поєднання відчуттів викликає приємні і неприємні почуття. Оскільки почуття задоволення веде до покращення життя i, за окремими винятками, діє позитивно, то необхідно створити молодій людині такі умови, щоб у житті було більше задоволення, ніж страждання, i щоб вона була більш сприйнятлива до задоволень, ніж до протилежного.

Будь-які функції організму пов'язані із задоволенням, якщо це дозволяє стан здоров'я та є достатній запас життєвої енергії. Саме тому здоров'я та наявність життєвої енергії можна вважати передумовою виникнення приємних позитивних почуттів, сприяє узгодженню рухів з почуттями [4.]. Виснаження організму є основною причиною неприємних і хворобливих почуттів. Аналогічно діє будь-яка хвороба.

Будь-яке почуття, якщо воно триває довго, ослаблюється. Тому одноманітна діяльність протягом тривалого часу знижує почуття задоволення. Людина перестає відчувати ті ж враження. Наприклад, найкрасивіші місця, якщо ми живемо довго серед них, перестають нам подобатися. Для того щоб підтримувати приємні почуття, необхідні різноманітні переживання і зміна видів діяльності.

Перша умова для розвитку та підтримки приємних почуттів - це вміння в усіх явищах, що відбуваються в нашому житті, бачити позитивні риси. Студентів необхідно націлювати на науково-дослідних заняттях спостерігати і сприймати в речах, людях, в подіях тільки позитивну сторону, одночасно аналізуючи шкідливість прояву негативізму. У житті і природі все змішано чудернацьки. Один скеровує свій погляд на все прекрасне, благородне, світле, і життя його стає радісним, інший вбачає тільки негативне, й це ставить його в неприємні обставини. Важливий аспект психологічного розвитку людини на юнацький період - інтелектуальне дозрівання. А тому на цьому шляху потрібно створити сприятливіші умови, усунути будь-який негатив.

Однак, по-різному підтримуючи приємні почуття, не варто допускати надмірних емоцій. Саме через цю незначну, на перший погляд, причину - почуття міри - суспільство зазнає надзвичайних проблем у всіх галузях. Різні типи збудження, предмети розкоші, розважальні заходи варто, наскільки це можливо, відсторонити в житті молоді. Повне усунення страждань $з$ життя юного покоління неможливе, але якби й було можливим, то небажане. Не завжди від добра можна дочекатись добра. Життя кожної людини - це наполегливий шлях до самоутвердження, на якому при подоланні перешкод зустрічаються невдачі і поразки, а значить і страждання. Тому студента як суб' єкта життя [5] в перспективі слід підготувати до неминучих труднощів. Таким чином, формування молодої людини не повинно відбуватися в "рожевих" тонах, бути розніженим, розслаблюючим і створювати ілюзію легкості та доступності в пошу- 
ках себе. Навпаки, доцільно формувати та розвивати твердість і стійкість, цілеспрямованість і наполегливість у подоланні труднощів, переживанні страждань та випробування моральних, фізичних якостей, що зустрічаються на шляху до самореалізації. Душу необхідно загартовувати так, як і тіло. Хто сильний духом, той незламний тілом.

Висновки. Викладач повинен вміло керувати складними душевними процесами, що передбачає дозування впливу тих чи інших почуттів, які б рівномірно наповнювали студентську душу необхідними компонентами для засвоєння об'єму знань, практичних умінь та навичок, формування особистих переконань та поглядів.

1. Позитивні і приємні почуття необхідно підтримувати та зберігати - це основний напрям контролю над ними. А основний принцип - дотримання міри, бо тривале почуття, навіть позитивне, може перерос-

\section{Література}

1. Власова О. І. Педагогічна психологія / О. І. Власова. K., 2005.-398 c.

2. Мельничук І. М. Вікова і педагогічна психологія / I. М. Мельничук. - Тернопіль, 2006. - 143 с.

3. Розе Н. А. Психомоторика взрослого человека / Н. А. Розе.- Ленинград, 1970.-190 с. ти у свою протилежність через надмірність. Тому контроль над почуттями є важливим елементом роботи викладача.

2. Людина наділена інтелектуальними та емоційними якостями, кожен акт своєї життєдіяльності вона супроводжує не лише осмисленням, а й реакцією своїх почуттів, які формуються змістом душевних процесів, впливом оточення, власне психодуховним станом, здоров'я і, водночас, здійснюється здоровий вплив на загальні чинники.

3. Основним правилом розвитку почуттів у студентів є необхідність відокремлення позитивних почуттів від негативних з одночасною стимуляцією перших і гальмуванням других, в чому надзвичайно важливу роль відіграє осмислення ставлення молодих людей до власних почуттів, їх аналіз, висновки щодо наслідків їх прояву.

4. Скрипніченко О. В. Вікова педагогічна психологія / О. В. Скрипніченко, Л. В. Долинська. -К., 2009. - 399 с.

5. Нікітіна І. В. Суб'єктивне самовизначення молодої людини в період навчання / І. В. Нікітіна. -К., 2008. - 187 с.

Отримано 29.05.14 